\title{
Camellisins A-C, Three New Triterpenoids from the Roots of Camellia sinensis
}

\author{
Chun LeI, ${ }^{a, \#}$ Zhuo Hu,,${ }^{c, \#}$ Jian-Xin Pu, ${ }^{*, a}$ Yuan-Yuan WAnG, ${ }^{a}$ Wei-Lie XIaO,${ }^{a}$ Ning-Bo Gong,,${ }^{b}$ Yan Li, ${ }^{a}$ \\ Yang Lu, ${ }^{b}$ Qi-Tai ZHENG, ${ }^{b}$ and Han-Dong SuN ${ }^{*, a}$ \\ ${ }^{a}$ State Key Laboratory of Phytochemistry and Plant Resources in West China, Kunming Institute of Botany, Chinese \\ Academy of Sciences; Kunming 650204, P. R. China: ${ }^{b}$ Institute of Materia Medica, Chinese Academy of Medical Sciences \\ \& Peking Union Medical College; Peking 100050, P.R. China: and ${ }^{c}$ College of Chemistry and Biotechnology, Yunnan \\ Nationalities University; Kunming 650204, P. R. China. \\ Received March 18, 2010; accepted April 23, 2010; published online April 26, 2010
}

Eighteen compounds, including three new triterpenoids, camellisins $A-C(1-3)$, were isolated from the roots of Camellia sinensis. Their structures were determined on the basis of detailed spectroscopic analysis.

Key words Camellia sinensis; triterpenoid; camellisin

Camellia sinensis is an evergreen shrub plant of the Theaceae family. Their leaves and leaf buds are used to produce tea. Since the tea was discovered for the first time in China $^{1)}$ in $2737 \mathrm{BC}$, it is at present, only next to water, the most popular beverage, and is currently grown and cultivated in at least 30 countries around the world. ${ }^{2)}$ Phytochemical and pharmacological studies of tea have provided convincing evidence that the polyphenolic antioxidants present in tea are capable of affording chemoprevention in cancer. ${ }^{2,3)}$ Root of C. sinensis is a common traditional Chinese medicine, which has been used to cure rheumatic and hypertensive cardiopathy, coronary heart disease and arrhythmia. Previous phytochemical studies of the roots have led to the identification of some sugars, phenolic components, steroids, and triterpene saponins. ${ }^{4,5}$ With the aim of searching new natural compounds with interesting biological activities, we carried out phytochemical investigations on the roots of this plant collected in China. Three new triterpenoids, camellisins A-C (1-3), together with 15 known compounds have been isolated. Here, we report the structure elucidation of these new triterpenoids on the basis of their spectroscopic data and the bioassay of their cytotoxicity against five kinds of the human tumor cell lines, including HL-60, SMMC-7721, A-549, PANC-1 and SK-BR-3.

\section{Results and Discussion}

Phytochemical studies on the $70 \%$ aqueous acetone extract of the roots of $C$. sinensis led to the isolation of three new triterpenoids, camellisins $\mathrm{A}-\mathrm{C}(\mathbf{1}-\mathbf{3})$, and 15 known compounds including one triterpenoid, ursolic acid, ${ }^{6}$ two steroids, chondrillasterol ${ }^{7)}$ and $\alpha$-spinasterone, ${ }^{8)}$ six phenolic com-

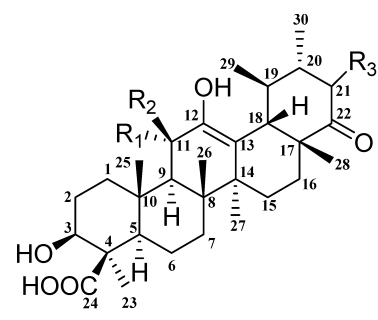

$1 \mathrm{R}_{1}=\mathrm{OH}, \mathrm{R}_{2}=\mathrm{H}, \mathrm{R}_{3}=\beta-\mathrm{OH}$

$2 \mathrm{R}_{1}=\mathrm{R}_{2}=\mathrm{O}, \mathrm{R}_{3}=\mathrm{H}$

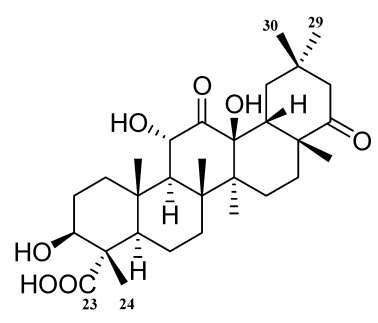

3 pounds, lariciresinol, ${ }^{9)}$ pinoresinol, ${ }^{10)}$ 4-O-methylcedrusin, ${ }^{11)}$ $(+)$-balanophonin, ${ }^{12)} \omega$-hydroxypropioguaiacone, ${ }^{13)}(E)$-ferulaldehyde, ${ }^{14)}$ and six other constituents, 5-megastigmene3,9-diol, $\left.{ }^{15}\right)$ 4,5-dihydroblumen-ol $\mathrm{A}^{16}{ }^{16}$ (6R,9R)-9-hydroxy4-megastigmen-3-one, ${ }^{17)}$ blumenol $\mathrm{B},{ }^{18)}$ glycerol 1-hexadecanoate, ${ }^{19)}$ and hexadecanoic acid. ${ }^{19)}$ The known compounds were determined by comparing their mass spectra and NMR data with those of literatures. The new compounds were characterized on the basis of comprehensive spectroscopic analysis.

Camellisin A (1) was obtained as colorless needle crystals from $\mathrm{MeOH}$. The high-resolution-electrospray mass spectrometry (HR-ESI-MS) exhibited a pseudo-molecular ion peak $[\mathrm{M}-\mathrm{H}]^{-}$at $m / z 517.3166$ (Calcd. 517.3165) corresponding to the molecular formula $\mathrm{C}_{30} \mathrm{H}_{46} \mathrm{O}_{7}$, indicating eight degrees of unsaturation. The ${ }^{1} \mathrm{H}-$ and ${ }^{13} \mathrm{C}-\mathrm{NMR}$ spectra displayed 30 carbon resonances comprising seven methyl groups (including five tertiary ones and two secondary ones), six $s p^{3}$ methylenes, eight $s p^{3}$ methines (three oxygenated at $\left.\delta_{\mathrm{C}} 78.9,70.6,77.7\right)$, one carbonic carbon $\left(\delta_{\mathrm{C}} 180.9\right)$, one carbonyl carbon $\left(\delta_{\mathrm{C}} 216.7\right)$, a pair of quaternary olefinic bond $\left(\delta_{\mathrm{C}} 148.6,112.8\right)$, and five quaternary $s p^{3}$ carbons (Table 1). This information, coupled with the molecular formula indicated that compound $\mathbf{1}$ was a triterpenoid with five rings and four hydroxyls.

The ${ }^{1} \mathrm{H}-{ }^{1} \mathrm{H}$ shift correlation spectroscopy (COSY) spectrum revealed five groups of correlations including $\mathrm{H}_{2}-1 / \mathrm{H}_{2}-$ 2/H-3, H-5/ $\mathrm{H}_{2}-6 / \mathrm{H}_{2}-7, \quad \mathrm{H}-9 / \mathrm{H}-11, \mathrm{H}_{2}-15 / \mathrm{H}_{2}-16, \quad \mathrm{H}-18 / \mathrm{H}-$ $19\left(\mathrm{H}_{3}-29\right) / \mathrm{H}-20\left(\mathrm{H}_{3}-30\right) / \mathrm{H}-21$ (Fig. 1). The heteronuclear multiple bond correlation (HMBC) spectrum displayed distinct correlations from five singlet methyl groups: from $\mathrm{H}_{3}-$ $24\left(\delta_{\mathrm{H}} 1.40\right)$ to $\mathrm{C}-3, \mathrm{C}-4, \mathrm{C}-5$; from $\mathrm{H}_{3}-25\left(\delta_{\mathrm{H}} 1.10\right)$ to $\mathrm{C}-1$, $\mathrm{C}-5$, C-9, C-10; from $\mathrm{H}_{3}-26\left(\delta_{\mathrm{H}} 1.09\right)$ to $\mathrm{C}-7, \mathrm{C}-8, \mathrm{C}-9$, C14; from $\mathrm{H}_{3}-27\left(\delta_{\mathrm{H}} 1.32\right)$ to $\mathrm{C}-13, \mathrm{C}-14, \mathrm{C}-15$; and from $\mathrm{H}_{3}$ $28\left(\delta_{\mathrm{H}} 1.03\right)$ to $\mathrm{C}-16, \mathrm{C}-17, \mathrm{C}-18$, and $\mathrm{C}-22$ (Fig. 1$)$. The COSY correlations above and the key HMBC cross peaks built up the five rings framework as shown and assigned three of the four hydroxyls to be located at C-3 $\left(\delta_{\mathrm{C}} 78.9\right)$, C$11\left(\delta_{\mathrm{C}} 70.6\right)$, and $\mathrm{C}-21\left(\delta_{\mathrm{C}} 77.7\right)$, respectively. The remained hydroxyl could only constructure an enol system with the olefinic bond of C-12 and C-13, which can be deduced by the HMBC correlations from $\mathrm{H}-9$ and $\mathrm{H}-18$ to $\mathrm{C}-12, \mathrm{H}_{3}-27$ and $\mathrm{H}-18$ to $\mathrm{C}-13$, respectively (Fig. 1). The carbonic acid was 
Table 1. ${ }^{1} \mathrm{H}$ - and ${ }^{13} \mathrm{C}$-NMR Data of Compounds $\mathbf{1}-\mathbf{3}\left(400,100 \mathrm{MHz}\right.$, in $\mathrm{C}_{5} \mathrm{D}_{5} \mathrm{~N}, \delta$ in ppm, $J$ in $\left.\mathrm{Hz}\right)$

\begin{tabular}{|c|c|c|c|c|c|c|}
\hline \multirow{2}{*}{ Position } & \multicolumn{2}{|l|}{1} & \multicolumn{2}{|l|}{2} & \multicolumn{2}{|l|}{3} \\
\hline & $\delta_{\mathrm{H}}$ & $\delta_{\mathrm{C}}$ & $\delta_{\mathrm{H}}$ & $\delta_{\mathrm{C}}$ & $\delta_{\mathrm{H}}$ & $\delta_{\mathrm{C}}$ \\
\hline $1 \alpha$ & $1.28^{a)}$ & & $1.21^{a)}$ & $40.1 \mathrm{t}$ & $1.39(\mathrm{~m})$ & \\
\hline $1 \beta$ & $2.41(\mathrm{~m})$ & $42.3 \mathrm{t}$ & $3.13(\mathrm{~m})$ & & $3.41^{a)}$ & $42.0 \mathrm{t}$ \\
\hline $2 \alpha$ & $1.67^{a)}$ & & $2.63(\mathrm{~m})$ & $29.0 \mathrm{t}$ & $2.54^{a)}$ & \\
\hline $2 \beta$ & $2.10^{a)}$ & $29.3 \mathrm{t}$ & $1.98(\mathrm{~m})$ & & $2.00^{a)}$ & $29.7 \mathrm{t}$ \\
\hline 3 & $3.15(\mathrm{dd}, 4.5,12.1)$ & $78.9 \mathrm{~d}$ & $3.41(\mathrm{dd}, 4.5,12.0)$ & $80.0 \mathrm{~d}$ & $3.44(\mathrm{dd}, 4.4,13.2)$ & $78.1 \mathrm{~d}$ \\
\hline 4 & & $49.4 \mathrm{~s}$ & & $49.4 \mathrm{~s}$ & & $50.0 \mathrm{~s}$ \\
\hline 5 & $0.98^{a)}$ & $57.8 \mathrm{~d}$ & $1.13^{a)}$ & $56.5 \mathrm{~d}$ & $1.19(\mathrm{dd}, 4.5,12.6)$ & $57.1 \mathrm{~d}$ \\
\hline $6 \alpha$ & $1.85^{a)}$ & & $2.23(\mathrm{~m})$ & $20.0 \mathrm{t}$ & $2.58(\mathrm{~m})$ & \\
\hline $6 \beta$ & $1.84^{a)}$ & $21.1 \mathrm{t}$ & $2.12(\mathrm{~m})$ & & $2.07(\mathrm{~m})$ & $20.1 \mathrm{t}$ \\
\hline $7 \alpha$ & $1.50(\mathrm{~m})$ & & $1.67(\mathrm{dd}, 4.0,13.0)$ & $33.5 \mathrm{t}$ & $1.53(\mathrm{~m})$ & \\
\hline $7 \beta$ & $1.39^{a)}$ & $35.3 \mathrm{t}$ & $1.44^{a)}$ & & $1.47(\mathrm{~m})$ & $34.7 \mathrm{t}$ \\
\hline 8 & & $44.1 \mathrm{~s}$ & & $42.0 \mathrm{~s}$ & & $43.5 \mathrm{~s}$ \\
\hline 9 & $1.72(\mathrm{~d}, 9.3)$ & $54.0 \mathrm{~d}$ & $2.75(\mathrm{~s})$ & $59.6 \mathrm{~d}$ & $1.92(\mathrm{~d}, 12.1)$ & $57.4 \mathrm{~d}$ \\
\hline 10 & & $39.6 \mathrm{~s}$ & & $38.2 \mathrm{~s}$ & & $40.6 \mathrm{~s}$ \\
\hline 11 & $4.07(\mathrm{~d}, 9.3)$ & $70.6 \mathrm{~d}$ & & $195.4 \mathrm{~s}$ & $5.51(\mathrm{~d}, 12.1)$ & $73.4 \mathrm{~d}$ \\
\hline 12 & & $148.6 \mathrm{~s}$ & & $146.6 \mathrm{~s}$ & & $212.8 \mathrm{~s}$ \\
\hline 13 & & $112.8 \mathrm{~s}$ & & $129.9 \mathrm{~s}$ & & $81.8 \mathrm{~s}$ \\
\hline 14 & & $42.3 \mathrm{~s}$ & & $45.1 \mathrm{~s}$ & & $45.8 \mathrm{~s}$ \\
\hline $15 \alpha$ & $1.12^{a)}$ & & $1.15^{a)}$ & & $1.24^{a)}$ & \\
\hline $15 \beta$ & $1.78^{a)}$ & $26.1 \mathrm{t}$ & $1.78^{a)}$ & $26.6 \mathrm{t}$ & $2.32(\mathrm{dd}, 4.4,12.1)$ & $22.0 \mathrm{t}$ \\
\hline $16 \alpha$ & $2.18^{a)}$ & 2034 & $2.17(\mathrm{dd}, 4.5,10.0)$ & $27.2 \mathrm{t}$ & $2.10^{a)}$ & \\
\hline $16 \beta$ & $1.20^{a)}$ & $29.3 \mathrm{t}$ & $1.28^{a)}$ & & $2.04^{a)}$ & $25.9 \mathrm{t}$ \\
\hline 17 & & $49.4 \mathrm{~s}$ & & $48.4 \mathrm{~s}$ & & $49.0 \mathrm{~s}$ \\
\hline 18 & $2.67(\mathrm{~d}, 11.7)$ & $48.6 \mathrm{~d}$ & $3.28(\mathrm{~d}, 11.0)$ & $48.4 \mathrm{~d}$ & $2.69(\mathrm{~d}, 12.3)$ & $47.5 \mathrm{~d}$ \\
\hline $19 \alpha$ & $2.00(\mathrm{~m})$ & & $1.89(\mathrm{~m})$ & $41.0 \mathrm{~d}$ & $1.28(\mathrm{dd}, 4.4,12.3)$ & \\
\hline $19 \beta$ & & $40.1 \mathrm{~d}$ & & & $2.39^{a)}$ & $41.7 \mathrm{t}$ \\
\hline 20 & $1.24(\mathrm{~m})$ & $48.8 \mathrm{~d}$ & $1.50(\mathrm{~m})$ & $39.0 \mathrm{~d}$ & & $33.8 \mathrm{~s}$ \\
\hline $21 \alpha$ & $4.10(\mathrm{~d}, 10.6)$ & & $2.43(\mathrm{dd}, 12.6,14.5)$ & $46.3 \mathrm{t}$ & $2.51(\mathrm{~d}, 12.6)$ & \\
\hline $21 \beta$ & & $77.7 \mathrm{~d}$ & $2.48(\mathrm{dd}, 5.5,14.5)$ & & $1.96(\mathrm{~d}, 12.6)$ & $49.0 \mathrm{t}$ \\
\hline 22 & & $216.7 \mathrm{~s}$ & & $214.4 \mathrm{~s}$ & & $217.5 \mathrm{~s}$ \\
\hline 23 & $1.40(\mathrm{~s})$ & $24.7 \mathrm{q}$ & $1.74(\mathrm{~s})$ & $24.7 \mathrm{q}$ & & $180.8 \mathrm{~s}$ \\
\hline 24 & & $180.9 \mathrm{~s}$ & & $180.4 \mathrm{~s}$ & $1.78(\mathrm{~s})$ & $24.9 \mathrm{q}$ \\
\hline 25 & $1.10(\mathrm{~s})$ & $15.3 \mathrm{q}$ & $1.58(\mathrm{~s})$ & $14.6 \mathrm{q}$ & $1.57(\mathrm{~s})$ & $14.7 \mathrm{q}$ \\
\hline 26 & $1.09(\mathrm{~s})$ & $18.5 \mathrm{q}$ & $1.19(\mathrm{~s})$ & $18.5 \mathrm{q}$ & $1.77(\mathrm{~s})$ & $20.5 \mathrm{q}$ \\
\hline 27 & $1.32(\mathrm{~s})$ & $24.0 \mathrm{q}$ & $1.48(\mathrm{~s})$ & $20.7 \mathrm{q}$ & $1.04(\mathrm{~s})$ & $17.0 \mathrm{q}$ \\
\hline 28 & $1.03(\mathrm{~s})$ & $21.0 \mathrm{q}$ & $1.17(\mathrm{~s})$ & $21.6 \mathrm{q}$ & $1.66(\mathrm{~s})$ & $26.7 \mathrm{q}$ \\
\hline 29 & $1.04(\mathrm{~d}, 6.6)$ & $16.6 \mathrm{q}$ & $0.92(\mathrm{~d}, 6.5)$ & $20.9 \mathrm{q}$ & $0.96(\mathrm{~s})$ & $31.5 \mathrm{q}$ \\
\hline 30 & $1.16(\mathrm{~d}, 6.6)$ & $17.0 \mathrm{q}$ & $1.05(\mathrm{~d}, 6.5)$ & $16.4 \mathrm{q}$ & $1.13(\mathrm{~s})$ & $28.6 \mathrm{q}$ \\
\hline HO-13 & & & & & $7.08(\mathrm{~s})$ & \\
\hline
\end{tabular}
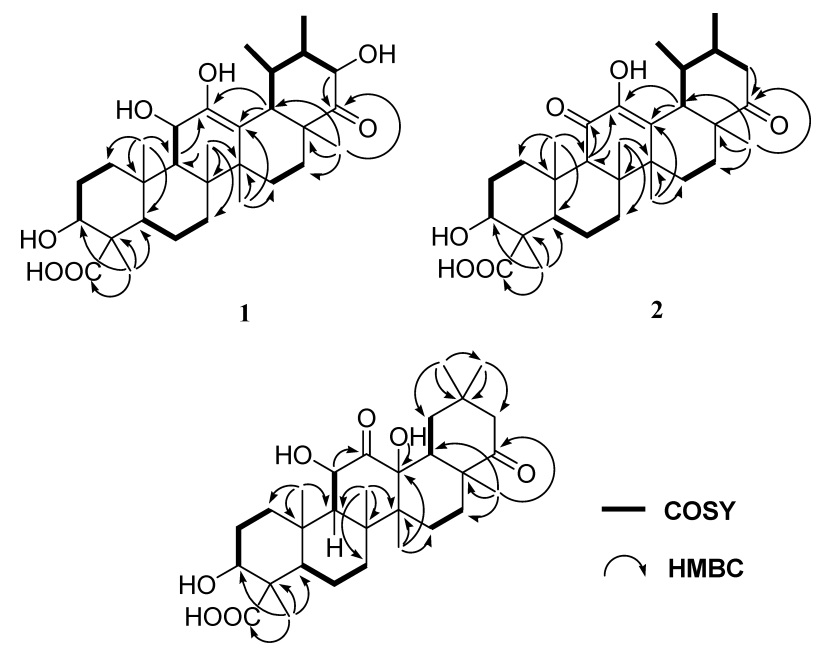

3

Fig. 1. ${ }^{1} \mathrm{H}-{ }^{1} \mathrm{H}$ COSY and Selected HMBC Correlations of $\mathbf{1}-\mathbf{3}$ assigned at $\mathrm{C}-23$ from the distinct HMBC correlations from $\mathrm{H}-3, \mathrm{H}-5$, and $\mathrm{H}_{3}-24$ to signal at $\delta_{\mathrm{C}} 180.9$ (Fig. 1). And the carbonyl carbon $\left(\delta_{\mathrm{C}} 216.7\right)$ was confirmed to be $\mathrm{C}-22$, since the HMBC correlations existed in both $\mathrm{H}-21$ and $\mathrm{H}_{3}-28$ with $\delta_{\mathrm{C}} 216.7$ (Fig. 1). Thus, the planar structure of compound $\mathbf{1}$ was established.

The relative stereochemistry of $\mathbf{1}$ was ascertained by the nuclear Overhauser effects (NOEs) and X-ray diffraction. From the biosynthetic point of view, $\mathrm{H}-5$ and $\mathrm{CH}_{3}-27$ were $\alpha$-orientations, while $\mathrm{H}-18, \mathrm{CH}_{3}-25, \mathrm{CH}_{3}-26$, and $\mathrm{CH}_{3}-28$ were $\beta$-orientations. ${ }^{20)}$ Thus, the rotating frame Overhauser enhancement (ROE) correlations of $\mathrm{H}-5$ with $\mathrm{CH}_{3}-23$ and of $\mathrm{H}-11$ with $\mathrm{CH}_{3}-25$ indicated both $\mathrm{CH}_{3}-23$ and HO-11 were $\alpha$-directed. Correlations of both $\mathrm{H}-18$ and $\mathrm{CH}_{3}-28$ with $\mathrm{CH}_{3}$ 29 suggested that $\mathrm{CH}_{3}-29$ was $\beta$-orientation, while $\mathrm{H}-19$ with $\mathrm{CH}_{3}-30$ and $\mathrm{H}-21$ indicated the $\alpha$-orientations of both $\mathrm{CH}_{3}-$ 30 and H-21 (Fig. 2). The X-ray diffraction analysis of compound 1 further confirmed its relative stereochemistry (Fig. $3)$. The circular dichroism (CD) spectrum of 1 showed the relatively strong $\pi \rightarrow \pi^{*}$ transition around $208 \mathrm{~nm}$ for the olefin group are positive, while the weak $n \rightarrow \pi^{*}$ transition 


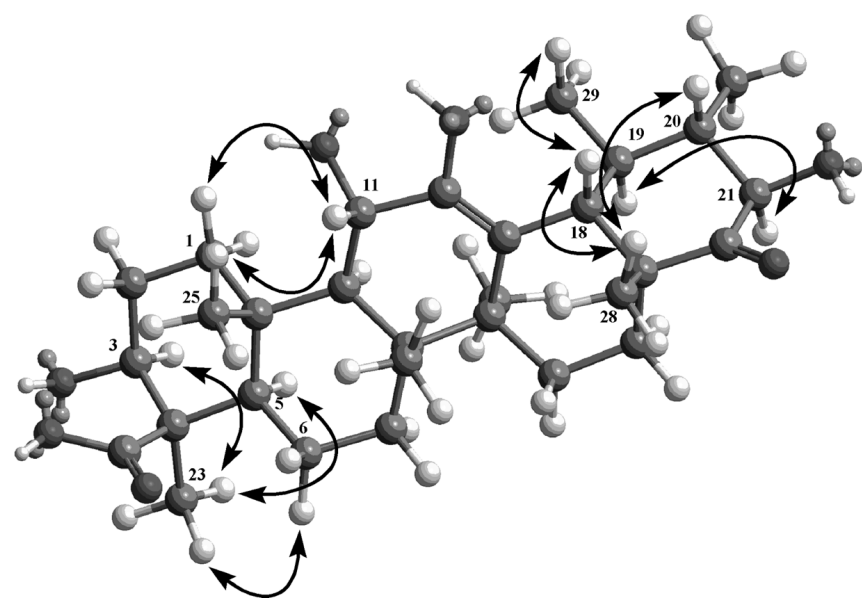

Fig. 2. Partial ROE Correlations of $\mathbf{1}$

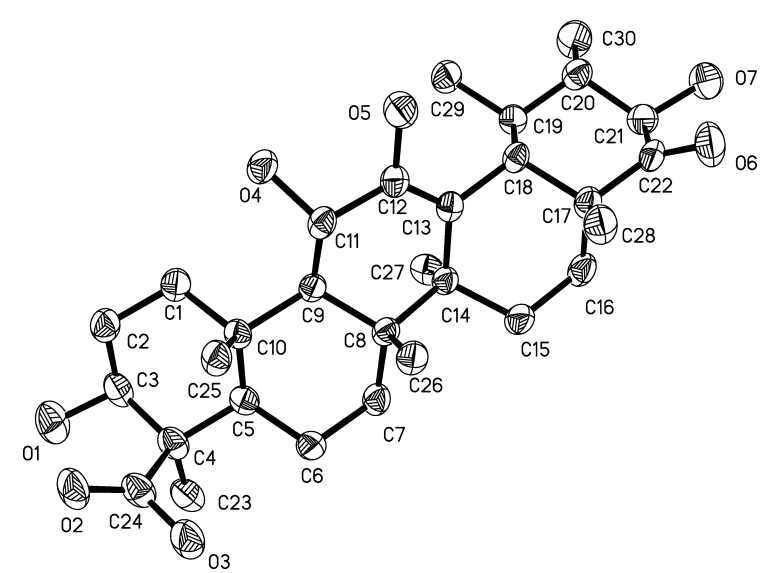

Fig. 3. X-Ray Crystal Structure of $\mathbf{1}$ Showing the Relative Configuration

around $285 \mathrm{~nm}$ for the cyclohexanone group is negative. Analysis of the Cotton effect according to the olefin octant rule $^{21)}$ and the cyclohexanone octant rule $^{22}$ indicated the rings $\mathrm{B} / \mathrm{C}$ is trans while the $\mathrm{D} / \mathrm{E}$ system is cis in $\mathbf{1}$. Thus, the absolute configuration of $\mathbf{1}$ was established as shown. Therefore, compound $\mathbf{1}$ was elucidated to be an ursane triterpenoid analogy, $3 \beta, 11 \alpha, 12,21 \beta$-tetrahydroxy-22-oxo-urs-12-en24-oic acid, named camellisin A.

Camellisin B (2) was isolated as colorless needle crystals in $\mathrm{MeOH}$. Its molecular formula, $\mathrm{C}_{30} \mathrm{H}_{44} \mathrm{O}_{6}$, was deduced from the positive HR-ESI-MS ion peak $[\mathrm{M}+\mathrm{Na}]^{+} \mathrm{m} / \mathrm{z}$ 523.3037 (Calcd 523.3036), requiring nine degrees of unsaturation. The ${ }^{13} \mathrm{C}$-NMR spectrum displayed 30 carbon signals, most of which were similar to those of compound $\mathbf{1}$. The main differences were restricted to the signals of rings $\mathrm{C}$ and E. Among them, two oxygenated carbon signals disappeared while a carbonyl carbon one appeared. The C-9 was slightly downfield shifted (Table 1) which indicated that the adjacent oxygenated C-11 in $\mathbf{1}$ was further oxygenated into the carbonyl carbon in 2 . The slightly up shift of C-12 and dramatically down shift of $\mathrm{C}-13$ indicated that the carbonyl carbon and the olefinic bond formed as an $\alpha, \beta$-unsaturated ketone moiety on ring $\mathrm{C}$ (Table 1$)$. This assumption was finally confirmed by the key HMBC correlations from $\mathrm{H}-9$ to $\mathrm{C}-11\left(\delta_{\mathrm{C}}\right.$ $195.4)$ and $\mathrm{C}-12\left(\delta_{\mathrm{C}} 146.6\right)$, from $\mathrm{H}-18$ to C-12 and C-13 $\left(\delta_{\mathrm{C}}\right.$ 129.9), and from $\mathrm{H}_{3}-27$ to $\mathrm{C}-13$ and $\mathrm{C}-14\left(\delta_{\mathrm{C}} 45.1\right)$ (Fig. 1$)$.
Thus, the oxygenated methine $\mathrm{C}-21$ in $\mathbf{1}$ was changed into a methylene in 2 , which can be confirmed from the ${ }^{1} \mathrm{H}-{ }^{1} \mathrm{H}$ COSY correlations of $\mathrm{H}-18 / \mathrm{H}-19 / \mathrm{H}-20 / \mathrm{H}_{2}-21$ (Fig. 1). ROE experiment of compound 2 showed correlations of $\mathrm{CH}_{3}-23$ with $\mathrm{H}-3$ and $\mathrm{H}-5$, which indicated the $R^{*}$ configuration of $\mathrm{C}-4$. The other chiral centers had the same stereochemistry as that of $\mathbf{1}$. Thus, compound $\mathbf{2}$ was established to be another ursane triterpenoid, 3 $\beta$,12-dihydroxy-11,22-dioxo-urs-12-en24-oic acid.

Camellisin C (3), colorless needle crystals in $\mathrm{MeOH}$, possessed a molecular formula of $\mathrm{C}_{30} \mathrm{H}_{46} \mathrm{O}_{7}$ as derived from its HR-ESI-MS ( $m / z$ 541.3148, $[\mathrm{M}+\mathrm{Na}]^{+}$, Calcd 541.3141). The ${ }^{1} \mathrm{H}-\mathrm{NMR}$ spectrum displayed seven quaternary methyl groups at $\delta_{\mathrm{H}} 0.96,1.04,1.13,1.57,1.66,1.77,1.78$, and a hydroxyl singlet signal at $\delta_{\mathrm{H}} 7.08$ (Table 1). The ${ }^{13} \mathrm{C}-\mathrm{NMR}$ data revealed 30 carbon signals including seven methyls, eight methylenes, five methines (two oxygenated), seven $s p^{3}$ quaternary carbon (one oxygenated), two carbonyl groups, and one carboxyl carbon. The 1D-NMR information, together with the eight degrees of unsaturation, indicated that compound 3 was a five ring triterpenoid with three hydroxyls. Detailed comparison of its 1D-NMR data with those of compounds $\mathbf{1}$ and $\mathbf{2}$ showed that they possessed the same rings $\mathrm{A}$ and $\mathrm{B}$. This can be further confirmed by the ${ }^{1} \mathrm{H}-{ }^{1} \mathrm{H}$ COSY correlations of $\mathrm{H}_{2}-1 / \mathrm{H}_{2}-2 / \mathrm{H}-3$ and $\mathrm{H}-5 / \mathrm{H}_{2}-6 / \mathrm{H}_{2}-7$, along with the key $\mathrm{HMBC}$ cross peaks of $\mathrm{H}_{3}-24$ with $\mathrm{C}-3$ and C-5, $\mathrm{H}_{3}-25$ with C-1, C-5, C-9, C-10, and $\mathrm{H}_{3}-26$ with C-7, C8, C-9, and C-14 (Fig. 1). The hydroxyl at $\delta_{\mathrm{H}} 7.08$ (s) was assigned to be located at $\mathrm{C}-13$ by the obvious HMBC correlation of $\delta_{\mathrm{H}} 7.08$ with $\mathrm{C}-13$. The third hydroxyl group was placed at C-11, as H-9 showed obvious COSY correlation with a doublet proton at $\delta_{\mathrm{H}} 5.51(J=12.1 \mathrm{~Hz}, \mathrm{H}-11)$ (Fig. 1). The distinct HMBC correlations of H-11 with $\delta_{\mathrm{C}} 212.8$ (s) assigned C-12 to be a carbonyl group (Fig. 1). The 6/6 membered rings $\mathrm{D}$ and $\mathrm{E}$ were established by ${ }^{1} \mathrm{H}-{ }^{1} \mathrm{H}$ COSY correlations of $\mathrm{H}_{2}-15 / \mathrm{H}_{2}-16$ and $\mathrm{H}-18 / \mathrm{H}_{2}-19$, along with three groups of $\mathrm{HMBC}$ correlations from $\mathrm{H}_{3}-27$ to $\mathrm{C}-13, \mathrm{C}-14, \mathrm{C}-$ 15 , from $\mathrm{H}_{3}-28$ to $\mathrm{C}-16, \mathrm{C}-17, \mathrm{C}-18$, and from $\mathrm{H}_{3}-29$ to $\mathrm{C}$ 19, C-20, C-21, C-30 (Fig. 1). The other carbonyl group was located at $\mathrm{C}-22$, which can be deduced from the key HMBC correlations of $\delta_{\mathrm{C}} 217.5$ (s) with both $\mathrm{H}_{3}-28$ and H-21 (Fig. 1).

The relative stereochemistry of $\mathbf{3}$ was established by the ROE correlations. As an oleanane triterpenoid, H-5, H-9, and $\mathrm{CH}_{3}-27$ were biogenetically $\alpha$-orientations, while $\mathrm{CH}_{3}-25$, $\mathrm{CH}_{3}-26$, and $\mathrm{CH}_{3}-28$ were biogenetically $\beta$-orientations, just as those of compound 1. ${ }^{20)}$ Thus, $\mathrm{CH}_{3}-24$ showed ROE correlation with $\mathrm{H}-2 \beta, \mathrm{H}-6 \beta$, and $\mathrm{CH}_{3}-26$, indicated the $\beta$-orientation of $\mathrm{CH}_{3}-24$ and the $S^{*}$ configuration of C-4. H-11, presenting correlation with both $\mathrm{CH}_{3}-25$ and $\mathrm{CH}_{3}-26$, and $\mathrm{HO}-$ 13 , exhibiting correlations with $\mathrm{H}-11$ and $\mathrm{H}-18$, suggested that all of them were $\beta$-orientations (Fig. 4). Thus, compound 3 was elucidated to be a new oleanane triterpenoid, $3 \beta, 11 \alpha$, $3 \beta$-trihydroxy-12,22-dioxo-olean-23-oic acid.

Compounds $\mathbf{1}-\mathbf{3}$ were tested for cytotoxicity against HL60 (human myeloid leukemia cell line), SMMC-7721 (human hepatocarcinoma cell line), A-549 (lung cancer cell line), PANC-1 (human pancreatic carcinoma) and SK-BR-3 (breast cancer cell line) cell lines. All compounds were inactive with $\mathrm{IC}_{50}$ values greater than $40 \mu \mathrm{M}$, while the positive control cisplatin showed $\mathrm{IC}_{50}$ values of $1.7,19.4,29.7,38.0$, and 


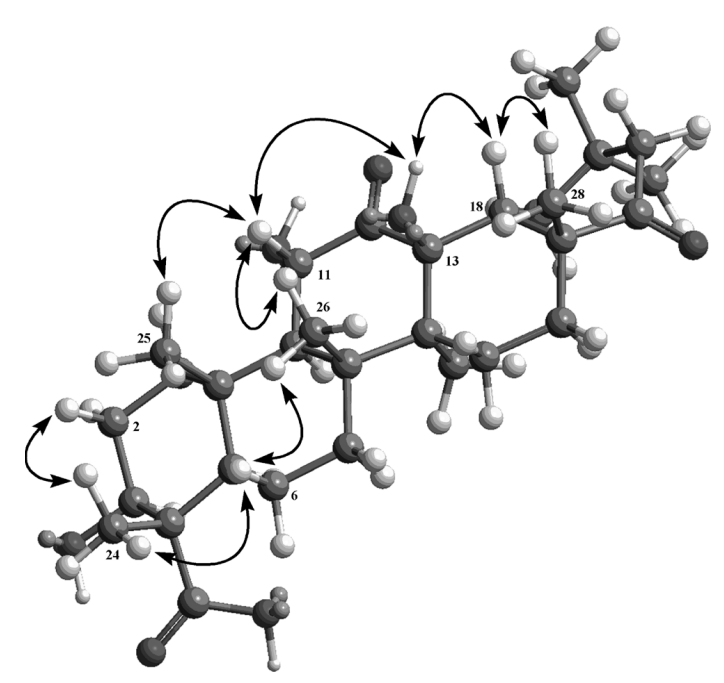

Fig. 4. Key ROE Correlations of $\mathbf{3}$

\section{$17.4 \mu \mathrm{M}$, respectively.}

\section{Experimental}

General Procedure Petroleum ether (PE, 60-90 ${ }^{\circ} \mathrm{C}$ ), EtOAc, $\mathrm{CHCl}_{3}$, Acetone, $\mathrm{MeOH}, \mathrm{EtOH}$, and $i$ - $\mathrm{PrOH}$ were analytical grade and produced by Sinopharm Chemical Reagent Co., Ltd., China. Column chromatography (CC) was performed on silica gel (200-300 mesh; Qingdao Marine Chemical Inc., Qingdao, People's Republic of China), Lichroprep RP-18 gel (40$63 \mu \mathrm{m}$, Merck, Darmstadt, Germany), and Sephadex LH-20 (Pharmacia). Fractions were monitored by TLC, and spots were visualized by spraying with $10 \% \mathrm{H}_{2} \mathrm{SO}_{4}$ in EtOH, followed by heating. Semi-preparative HPLC was performed on an Agilent 1100 liquid chromatograph with a Zorbax SB-C $\mathrm{C}_{18}$, $9.4 \mathrm{~mm} \times 25 \mathrm{~cm}$ column. Melting point was obtained on an XRC-1 apparatus and was uncorrected. Optical rotations were measured on a JASCO DIP-370 digital polarimeter. CD spectra were measured on a JASCO J-810 spectropolarimeter. UV data were obtained using a UV-210A spectrometer. IR spectra were obtained on a Bio-Rad FtS-135 spectrophotometer with $\mathrm{KBr}$ pellets. MS were recorded on a VG Auto Spec-3000 spectrometer. NMR spectra were obtained on a Bruker DRX-400 instrument with TMS as an internal standard.

Plant Material The roots of $C$. sinensis were collected in Zhejiang province, China, in July 2004, and identified by Prof. Xi-Wen Li, Kunming Institute of Botany. A voucher specimen (No. 20040910) has been deposited in the Herbarium of the Kunming Institute of Botany, Chinese Academy of Sciences.

Extraction and Isolation The air-dried and powdered roots $(12 \mathrm{~kg})$ of C. sinensis were extracted with $70 \%$ aqueous Acetone $(3 \times 301)$ at room temperature to yield an extract, which was successively extracted with petroleum ether and EtOAc. The EtOAc extract was evaporated to dryness under reduced pressure to give an extract $(227 \mathrm{~g})$ that was separated by Si gel CC ( $2 \mathrm{~kg}, 100-200 \mathrm{mesh}$ ) and eluted with a petroleum ether/ethyl acetate gradient system $(9: 1,8: 2,7: 3,6: 4,5: 5)$ to give fractions $1-5$. Fraction 1 $(30 \mathrm{~g}), 2(20 \mathrm{~g})$ and $3(15 \mathrm{~g})$ were subjected to CC (200-300 mesh) with petroleum ether/ethyl acetate $(40: 1)$, petroleum ether/ethyl acetate $(20: 1)$, and petroleum ether $i-\mathrm{PrOH}$, respectively, affording ursolic acid $(16 \mathrm{mg})$, chondrillasterol $(254 \mathrm{mg}), \alpha$-spinasterone $(10 \mathrm{mg})$, glycerol 1-hexadecanoate $(36 \mathrm{mg})$, and hexadecanoic acid $(13 \mathrm{mg})$. Fraction $4(10 \mathrm{~g})$ was subjected to $\mathrm{CC}\left(200-300\right.$ mesh) with $\mathrm{CHCl}_{3} /$ acetone $(20: 1)$ to afford 3 fractions, which were further purified by semipreparative $\mathrm{HPLC}\left(\mathrm{MeOH} / \mathrm{H}_{2} \mathrm{O}\right)$ to give compounds pinoresinol (62 mg), 5-megastigmene-3,9-diol $(27 \mathrm{mg})$, and $(6 R, 9 R)$-9-hydroxy-4-megastigmen-3-one $(3 \mathrm{mg})$. Fraction $5(110 \mathrm{~g})$ was subjected to CC, Sephadex LH-20 (MeOH), RP-18, preparative and semipreparative HPLC $\left(\mathrm{MeOH}-\mathrm{H}_{2} \mathrm{O}\right)$ to give compound camellisin A $(1,56 \mathrm{mg})$, camellisin B (2,160 mg), camellisin C (3,33 mg), lariciresinol (10 mg), 4-Omethylcedrusin $(8 \mathrm{mg}),(+)$-balanophonin $(12 \mathrm{mg}), \omega$-hydroxypropioguaiacone $(15 \mathrm{mg}),(E)$-ferulaldehyde $(4 \mathrm{mg}), 4,5$-dihydroblumen-ol A $(14 \mathrm{mg})$, and blumenol B (8 mg).

Camellisin A (1): Colorless needle crystals in $\mathrm{MeOH}$; mp 187-188 ${ }^{\circ} \mathrm{C}$; $[\alpha]_{\mathrm{D}}^{24.4}+18.1\left(c=0.09, \mathrm{C}_{5} \mathrm{H}_{5} \mathrm{~N}\right) ; \mathrm{CD} \lambda_{\max }(c=0.28, \mathrm{MeOH}) \mathrm{nm}(\Delta \varepsilon) 203.5$ $(+53.8), 208(+52.4), 212(+47.0), 217(+35.6), 241(-13.9), 245$
(-15.8), $285(-7.9), 301(-9.8)$; UV $\lambda_{\max }(\mathrm{MeOH}) \mathrm{nm}(\log \varepsilon): 207$ (4.15), 360 (1.90), 365 (1.88), 390 (1.87); IR (KBr) $v_{\max } \mathrm{cm}^{-1}: 3421,2980,2934$, $2872,1697,1640,1459,1379,1311,1275,1247,1194,1089,1063,1029$, 1002, 985; ${ }^{1} \mathrm{H}-$ and ${ }^{13} \mathrm{C}-\mathrm{NMR}$ : listed in Table 1; ESI-MS (neg.): $\mathrm{m} / \mathrm{z} 1036$ $[2 \mathrm{M}]^{-}$(6), $517[\mathrm{M}-\mathrm{H}]^{-}$(100), 501 (7); HR-ESI-MS (neg.): $m / z 517.3166$ $\left([\mathrm{M}-\mathrm{H}]^{-}, \mathrm{C}_{30} \mathrm{H}_{45} \mathrm{O}_{7}\right.$, Calcd 517.3165).

X-Ray Crystal Structure Analysis of 1: $\left(\mathrm{C}_{30} \mathrm{H}_{46} \mathrm{O}_{7}\right)_{2} \cdot\left(\mathrm{CH}_{3} \mathrm{OH}\right)_{3} \cdot \mathrm{H}_{2} \mathrm{O}$ $(\mathrm{M}=518.68)$, triclinic $P_{1}: a=11.1828$ (12) $\AA, b=12.0281 \quad$ (13) $\AA, c=$ $13.6749(15) \AA, \alpha=110.2639(10)^{\circ}, \beta=90.0150(20)^{\circ}, \gamma=114.4298(10)^{\circ}$, $Z=2, V=1548.7$ (3) $\AA^{3}, D_{\text {calcd }}=1.235 \mathrm{~g} / \mathrm{cm}^{3}, R=0.069, R w=0.168$. From a crystal sized $0.38 \times 0.13 \times 0.10 \mathrm{~mm}, 11727$ independent reflections were measured on a Bruker Nonius area detector with Mo $K \alpha$ radiation, of which 6946 were observed $\left(|F|^{2} \geq 2 \sigma|F|^{2}\right)$. The structure was solved by direct methods (SHELXS-97) and expanded by Fourier techniques, refined by the program NOMCSDP and full-matrix least-squares calculations. Drawing of the molecule was achieved with ORTEP. Crystallographic data for the structure of $\mathbf{1}$ have been deposited in the Cambridge Crystallographic Data Centre (deposition number CCDC 769198). Copies of the data can be obtained free of charge via www.ccdc.acm.ac.Uk/conts/retrieving.html [or from the Cambridge Crystallographic Data Centre, 12 Union Road, Cambridge CB21EZ, U.K.; FAX (+44) 1223-336-033; or deposit@ ccdc.cam.ac.uk].

Camellisin B (2): Colorless needle crystals in $\mathrm{MeOH}$; mp 189-190 ${ }^{\circ} \mathrm{C}$; $[\alpha]_{\mathrm{D}}^{24.3}+131.3\left(c=0.15, \mathrm{C}_{5} \mathrm{H}_{5} \mathrm{~N}\right) ; \mathrm{UV} \lambda_{\max }(\mathrm{MeOH}) \mathrm{nm}(\log \varepsilon): 202(3.88)$, 287 (4.20), 374 (2.70); IR (KBr) $v_{\max } \mathrm{cm}^{-1}: 3426,2974,2933,2874,1694$, $1665,1637,1460,1388,1379,1363,1307,1284,1252,1191,1166,1040$; ${ }^{1} \mathrm{H}$ - and ${ }^{13} \mathrm{C}-\mathrm{NMR}$ : listed in Table 1; electron ionization-mass spectrometry (EI-MS): $m / z(\%): 500[\mathrm{M}]^{+}(83), 485\left[\mathrm{M}-\mathrm{CH}_{3}\right]^{+}(100), 471(20), 317(56)$, 303 (62), 233 (80); HR-ESI-MS (pos.): $m / z 523.3037$ ([M+Na $]^{+}$, $\mathrm{C}_{30} \mathrm{H}_{44} \mathrm{O}_{6} \mathrm{Na}$, Calcd 523.3036).

Camellisin C (3): Colorless needle crystals in $\mathrm{MeOH}$; mp 206-208 ${ }^{\circ} \mathrm{C}$; $[\alpha]_{\mathrm{D}}^{24.4}+10.0\left(c=0.10, \mathrm{C}_{5} \mathrm{H}_{5} \mathrm{~N}\right) ; \mathrm{UV} \lambda_{\max }(\mathrm{MeOH}) \mathrm{nm}(\log \varepsilon): 197(3.40)$, 206 (3.67), 352 (0.67); IR (KBr) $v_{\max } \mathrm{cm}^{-1}: 3430,3004,2977,2955,2875$, $1738,1709,1673,1637,1475,1461,1401,1369,1301,1276,1229,1184$, 1152, 1033; ${ }^{1} \mathrm{H}-$ and ${ }^{13} \mathrm{C}-\mathrm{NMR}$ : listed in Table 1; ESI-MS (pos.): $\mathrm{m} / \mathrm{z}(\%)$ : $1059[2 \mathrm{M}+\mathrm{Na}]^{+}(5), 557[\mathrm{M}+\mathrm{K}]^{+}(6), 541[\mathrm{M}+\mathrm{Na}]^{+}(100)$; HR-ESI-MS (pos.): $m / z 541.3148\left([\mathrm{M}+\mathrm{Na}]^{+}, \mathrm{C}_{30} \mathrm{H}_{46} \mathrm{O}_{7} \mathrm{Na}\right.$, Calcd 541.3141).

Cytotoxicity Assay The following human tumor cell lines were used: HL-60 (human myeloid leukemia cell line), SMMC-7721 (human hepatocarcinoma cell line), A-549 (lung cancer cell line), PANC-1 (human pancreatic carcinoma) and SK-BR-3 (breast cancer cell line). All the cells were cultured in RPMI-1640 or Dulbecco's modified Eagle's medium (DMEM) (Hyclone, Logan, UT, U.S.A.), supplemented with $10 \%$ fetal bovine serum (Hyclone, U.S.A.) at $37^{\circ} \mathrm{C}$ in a humidified atmosphere with $5 \% \mathrm{CO}_{2}$. Cell viability was assessed by conducting colorimetric measurements of the amount of insoluble formazan formed in living cells based on the reduction of 3(4,5-dimethylthiazol-2-yl)-2,5-diphenyltetrazolium bromide (MTT) (Sigma, St. Louis, MO, U.S.A.). Briefly, $100 \mu$ adherent cells were seeded into each well of a 96-well cell culture plate and allowed to adhere for $12 \mathrm{~h}$ before drug addition, while suspended cells were seeded just before drug addition, both with initial density of $1 \times 10^{5}$ cells $/ \mathrm{ml}$ in $100 \mu \mathrm{l}$ medium. Each tumor cell line was exposed to the tested compound at various concentrations in triplicates for $48 \mathrm{~h}$, with $\mathrm{cis}$-platin (Sigma, U.S.A.) as positive control. After the incubation, MTT $(100 \mu \mathrm{g})$ was added to each well, and the incubation continued for $4 \mathrm{~h}$ at $37^{\circ} \mathrm{C}$. The cells were lysed with $100 \mu \mathrm{l} 20 \%$ sodium dodecyl sulfate (SDS)-50\% N,N-dimethylformamide (DMF) after removal of $100 \mu 1$ medium. The optical density of the lysate was measured at $595 \mathrm{~nm}$ in a 96-well microtiter plate reader (Bio-Rad 680, U.S.A.). The $\mathrm{IC}_{50}$ value of each compound was calculated by the Reed and Muench's method.

Acknowledgment This work was supported financially by the NSFC (No. 20902093 to J.-X. Pu), State Key Laboratory of Phytochemistry and Plant Resources in West China (No. P2008-ZZ13), the Major State Basic Research Development Program of China (No. 2009CB522300), the Western Doctoral Foundation of Chinese Academy of Sciences (J.-X. Pu).

\section{References}

1) Harbowy M. E., Balentine E. A., Crit. Rev. Plant Sci., 16, 415-480 (1997).

2) Katiyar S. K., Mukhtar H., Int. J. Oncol., 8, 221-238 (1996).

3) Ahmad N., Katiiyar S. K., Mukhtar H., "Nutrition and Chemical Toxicity," ed. by Ioannides C., John Wiley \& Sons, West Sussex, England, 1998, pp, 301-343.

4) Lu Y., Umeda T., Yagi A., Sakata K., Chaudhuri T., Ganguly D. K., Sarma S., Phytochemistry, 53, 941—946 (2000). 
5) Chaudhuri T., Das S. K., Vedasiromoni J. R., Ganguly D. K., J. Indian Chem. Soc., 74, 166 (1997).

6) Kikuchi T., Matsuda S., Kadota S., Sakai Y., Namba T., Watanabe K., Dissanayake D. M. R. B., Chem. Pharm. Bull., 32, 3906-3911 (1984).

7) Yu D. L., Zhang Q., Zhang H. Y., Pan J. X., Nat. Prod. Res. Dev., 9, 14-18 (1997).

8) Zhou S. M., Zhou K., Xiao D. J., Nat. Prod. Res. Dev., 17, 428-430 (2005).

9) Erdemoglu N., Sahin E., Sener B., Ide S., J. Mol. Struct., 692, 57-62 (2004).

10) Antonio G. G., Rafael E. R., Carmen M., J. Nat. Prod., 52, 1139 1142 (1989).

11) Luc P., Tess D. B., Magda C., Arnold V., J. Nat. Prod., 56, 899-906 (1993).

12) Tsutomu W., Yoshimi N., Tadataka N., Phytochemistry, 66, 589—597 (2005).

13) Hans A., Markus S., Manuel A. C., Phytochemistry, 27, 1835-1841
(1988).

14) Heba H. B., Mahmoud A. M. N., Joachim B., Michael L., Phytochemistry, 26, 1837-1838 (1987).

15) Hideaki O., Zhong X. N., Hirata E., Shinzato T., Takeda Y., Chem. Pharm. Bull., 49, 1093-1097 (2001).

16) Antonio G. G., Jose A. G., Angel G. R., Ignacio A. J., J. Nat. Prod., 57, 400-402 (1994).

17) Brigida D. A., Marina D. G., Antonio F., Pietro M., Palma O., Fabio T., Phytochemistry, 65, 497-505 (2004).

18) Mark A. S., Francis I. L., Williams P. J., J. Agric. Food Chem., 38, 2045-2049 (1990).

19) Rajib K. M., Yoshinori F., Katsumi K., Phytochemistry, 37, 16411643 (1994).

20) Xu R., Fazio G. C., Matsuda S. P. T., Phytochemistry, 65, 261-291 (2004).

21) Scott A. I., Wrixon A. D., Tetrahedron, 26, 3695-3715 (1970).

22) Moffitt W., Woodward R. B., Moscowitz A., Klyne W., Djerassi C., J. Am. Chem. Soc., 83, 4013-4018 (1961). 